\section{RSP}

http://www.rsp.fsp.usp.br/
Revista de Saúde Pública

\title{
Aspects of work and sleep associated with work ability in regular aviation pilots
}

\author{
Pollyanna Pellegrino' iD, Elaine Cristina Marqueze"l iD
}

I Universidade Católica de Santos. Programa de Pós-Graduação em Saúde Coletiva. Santos, SP, Brasil

" Universidade Católica de Santos. Departamento de Epidemiologia. Programa de Pós-Graduação em Saúde Coletiva. Santos SP, Brasil

\section{ABSTRACT}

OBJECTIVE: Analyze the association of work organization and sleep aspects with work ability in regular aviation pilots.

METHODS: This is a cross-sectional epidemiological study with 1,234 regular aviation pilots who worked domestic and international flights, affiliated with the Brazilian Association of Civil Aviation Pilots. Data collection employed online questionnaire. We compared proportions using Pearson's Chi-squared or Fisher's exact hypothesis tests. Then, we conducted Poisson analysis, with robust variance, to test factors associated with moderate or low work ability.

RESULTS: The prevalence of moderate or low work ability was $43.3 \%$. We found that selfperception of insufficient sleep ( $\mathrm{PR}=1.29$; 95\%CI 1.06-1.57), increased perception for fatigue (PR = 1.51; 95\%CI 1.24-1.84), more than 65 flight hours per month (PR = 1.22; 95\%CI 1.01-1.46), less than 10 days of time off per month ( $\mathrm{PR}=1.27$; 95\%CI 1.04-1.55), and frequent operational delays ( $\mathrm{PR}=1.23$; 95\%CI 1.02-1.48) were factors associated with moderate or low work ability.

CONCLUSIONS: Work organization was a determining factor for decreased work ability, especially concerning aspects related to rest and its influence on the sleep of pilots.

DESCRIPTORS: Pilots. Work Ability Evaluation. Sleep. Working Conditions. Occupational Health.

\footnotetext{
Correspondence:
}

Elaine Cristina Marqueze

Av. Conselheiro Nébias, 300

Vila Mathias

11015-002 Santos, SP, Brasi

E-mail: elaine.marqueze

@unisantos.br

Received: Nov 8, 2016

Approved: Feb 24, 2018

How to cite: Pellegrino $P$,

Marqueze EC. Aspects of work and

sleep associated with work ability

in regular aviation pilots. Rev

Saude Publica. 2019;53:16.

Copyright: This is an open-access article distributed under the terms of the Creative Commons Attribution License, which permits unrestricted use, distribution, and reproduction in any medium, provided that the original author and source are credited. 


\section{INTRODUCTION}

In recent decades, regular aviation has grown significantly and is part of a process of transformation of the production system, with changes also in the organization and management of air transport ${ }^{9}$. These data demonstrate the importance of the sector for the economy, in air transportation of both passengers and freight ${ }^{9}$. According to the Air Transport Yearbook of the Brazilian National Civil Aviation Agency (ANAC), the number of paid passengers transported by plane in Brazil more than doubled in 10 years, from 26.8/100,000 inhabitants in 2005 to 58.7/100,000 inhabitants in 2014. On the other hand, the number of pilots of Brazilian companies grew only $21 \%$ over this period ${ }^{a}$. Such increased demand with no increase in staff has been negatively associated with the health of pilots, which is regulated by civil aviation standards and is responsibility of the State ${ }^{9}$.

This new context in aviation leads pilots to overloading, higher frequency of changes in schedule, psychological pressure, and stress, affecting their health and endangering the safety of flights ${ }^{14}$. However, these professionals need training and capacity to perform their job. Ilmarinen ${ }^{8}$ argues that this ability is a process of interaction between the resources of human beings and their work. Worker-related resources are their functional capacities; physical, mental, and social health; education; competence; values; attitudes and motivation. This is a dynamic process, which undergoes numerous changes over work life, mainly related to functional aging 8 .

Studies with airline pilots show that this category typically presents several sleep and health problems, especially excessive sleepiness, unintentional naps, and fatigue ${ }^{14,20,23}$. However, such studies are still incipient, and knowing characteristics of the work and health of these professionals is necessary to enable the action of public policies and make prevention and health promotion activities effective.

In this context, this article aims to analyze the association of work organization and sleep aspects with work ability in regular aviation pilots.

\section{METHODS}

Cross-sectional epidemiological study, with pilots (captains and copilots) of Brazilian regular aviation, of domestic and international flights routes, affiliated with the Brazilian Association of Civil Aviation Pilots (ABRAPAC). All pilots affiliated with the ABRAPAC $(2,530)$ were invited to participate in the study using email and 1,234 participated in the study (48.8\%). According to the ANAC , the number of pilots associated with the ABRAPAC represented approximately half of the Brazilian regular aviation pilots at the time of this study (5,956 pilots). It should be noted we used convenience sampling, since only pilots associated with the ABRAPAC were invited to participate in the study.

Initially, sample size was estimated to meet the objectives of the research "Fadiga crônica, condições de trabalho e saúde de pilotos brasileiros” [Chronic fatigue, working conditions, and health of Brazilian pilots] $]^{\mathrm{b}}$, with which this study is associated. Thus, sample power

a Agência Nacional de Aviação Civil, Superintendência de Acompanhamento de Serviços Aéreos, Gerência de Acompanhamento de Mercado. Anuário do Transporte Aéreo 2014. Brasília (DF):ANAC; 2014

${ }^{\mathrm{b}}$ Marqueze EC, Diniz DHMD, Nicola AC. Fadiga crônica, condições de trabalho e saúde em pilotos brasileiros. São Paulo: Associação Brasileira de Pilotos da Aviação Civil - ABRAPAC; 2014. Available from: https://pilotos.org.br/pressrelease-pesquisa-de-fadiga/ was estimated a posteriori ( $\mathrm{G}^{*}$ Power 3.1.4 software), to evaluate the internal validity of the results found in this study. We found $99 \%$ sample power, with $95 \%$ confidence interval $(\alpha=5 \%)$ to detect prevalence ratios equal to or greater than 1.20 as significant, having as parameter the prevalence of moderate or poor work ability (43.3\%).

Study variables were: sociodemographic characteristics and work, sleep, and lifestyle aspects.

* Sociodemographic characteristics:

- Sex;

- Age, dichotomized from mean age; 
- Educational level.

*Work aspects:

- Current function;

- Flight routes;

- Monthly flight hours, dichotomized from mean;

- Average days off per month;

- Maximum number of consecutive days of work in the last six months, dichotomized from mean;

- Maximum number of consecutive nights of work in the last six months;

- Frequency of operational flight delays;

- Time working as pilot, dichotomized from mean;

- Time working in the night shift;

- Quality of place for rest on plane, dichotomized from mean;

- End time of night shift;

- Need for recovery after work (evaluated using the scale proposed by Veldhoven and Broersen26, with the $0-100$ points score classified by tercile: less, moderate, and greater need for recovery) (Cronbach's alpha 0.81);

- Occupational stress was evaluated by the demand, control, and social support questionnaire Job Stress Scale, using the version adapted to Portuguese2. This questionnaire evaluates the occupational stressors and according to the demands and the control is categorized into: low job strain (high control and low demand), high job strain (low control and high demand), passive work (low control and low demand), and active work (high control and high demand). Cronbach's alpha for the demand questionnaire was 0.72 , for control 0.50 , and for social support 0.81 .

* Sleep and lifestyle aspects:

- Perception of chronotype, evaluated using a single question taken from the Karolinska sleep questionnaire';

- Perception of sufficient sleep, evaluated using a single question taken from the Karolinska sleep questionnaire';

- Perception of sleep quality, evaluated using a single question taken from the Karolinska sleep questionnaire';

- Chance of developing obstructive sleep apnea syndrome, evaluated using the Berlin questionnaire ${ }^{17}$ (Cronbach's alpha 0.67);

- Excessive sleepiness, evaluated using the Epworth sleepiness scale (Cronbach’s alpha 0.81);

- Perception of fatigue, evaluated using the Yoshitake questionnaire ${ }^{27}$ (Cronbach's alpha 0.93);

- Unintentional nap during work, evaluated using a single question taken from the Karolinska sleep questionnaire';

- Symptoms of insomnia, evaluated using seven questions of the Karolinska Sleep Questionnaire ${ }^{1}$, index proposed by Nordin et al. ${ }^{18}$ (Cronbach's alpha 0.88 );

- Weekly physical activity time, categorized into $\geq 150$ minutes/week or $<150$ minutes/week ${ }^{19}$. 
To evaluate work ability (dependent variable), we used the version translated to Portuguese ${ }^{25}$ of the work ability index (WAI), which is based on the individuals' self-perception of their work ability (Cronbach's alpha 0.82). By estimating the score, the work ability of all pilots was classified into great (45-49 points), good (41-44 points), moderate (37-40 points), or low $(7-36)^{10}$. These cut-off points were adopted because the sample under study is essentially composed of young adult workers ( $74.2 \%$ of the pilots were aged up to 45 years) and this research aims to discuss the factors associated with low or moderate work ability, so preventive actions can be proposed based on the results. It should be noted that, for the Poisson regression analysis, we grouped the categories low or moderate (tested) and good or great (reference).

The variables were described using absolute and relative frequencies. We compared proportions using Pearson's Chi-squared or Fisher's exact hypothesis tests. Given the type of study (cross-sectional) and the high prevalence of the outcome, we chose Poisson regression, with robust variance, to analyze the factors associated with moderate or low work ability. Independent variables with $\mathrm{p}<0.20$ in the hypotheses tests were tested in the multiple model, in decreasing order of statistical significance (stepwise backward technique). The model was adjusted for age and sex variables, because these variables showed no differences between the proportions of work ability. The significance level adopted in all tests was $5 \%$. We used Stata 12.0 (Stata corp, Texas, USA) for statistical analyses.

This study was approved by the Research Ethics Committee of the Federal Institute of Education, Science, and Technology of São Paulo (Protocol 625,158).

\section{RESULTS}

Most pilots interviewed were male (97.1\%), aged under 39 years (52.4\% - mean age 39.1 years, $\mathrm{SD}=9.8$ years), with educational level above that required for exercise of the profession (71.3\%), had a partner (84.4\%), did not live in the same location of their contractual basis (53.8\%), and held the position of domestic pilot (51.7\%), followed by domestic copilots (39.1\%). The prevalence of moderate or low work ability was $43.3 \%$.

Compared with pilots with great or good work ability, there was a higher proportion of pilots with moderate or low work ability who practiced less than 150 minutes of physical activity per week, who reported sleeping insufficiently and sleeping very poorly, who presented high chance of developing obstructive sleep apnea, with excessive sleepiness, with higher perception of fatigue, who presented unintentional naps during work, and who presented symptoms of insomnia. While as to occupational variables, the group with moderate or low work ability showed higher proportion of pilots with function of domestic and international captain, who worked in international flight routes, with more monthly flight hours than the group average, with less than nine days off per month, with seven consecutive days of work or more, who often had operational delays, who had worked longer in the profession and more time on the night shift, who assessed the quality of the place of rest on the plane as poor, who ended the night shift too late, with greater need for recovery after work and with a work classified as active and also low job strain. All these differences were statistically significant $(p<0.05)$ (Table 1).

In the bivariate model, the following variables were associated with low or moderate work ability: insufficient sleep, poor sleep, high chance for development of obstructive sleep apnea syndrome, unintentional naps during work, symptoms of insomnia, excessive sleepiness, high perception of fatigue, international flight routes, 66 or more monthly flight hours, up to nine days off per month, seven or more consecutive days of work, frequent operational delays, career of 11 to 20 years working as a pilot, 11 to 15 years working on the night shift, assessment of the place for rest on the plane as poor, end of night shift between 8:01 am and 12:00 pm, and moderate and greater need for recovery after work. Factors of protection for low or moderate work ability included: being international captain and domestic copilot, working as pilot for 21 to 30 years, and having passive work with high job strain (Table 2). 
Table 1. Work ability related to sociodemographic, lifestyle, sleep, and work characteristics. Brazil, 2017.

\begin{tabular}{|c|c|c|c|c|}
\hline \multirow[t]{2}{*}{ Variable } & \multirow[t]{2}{*}{ Category } & \multirow{2}{*}{$\begin{array}{c}\text { Great or good } \\
\text { work ability } \\
\text { n }(\%)\end{array}$} & \multirow{2}{*}{$\begin{array}{c}\begin{array}{c}\text { Moderate or low } \\
\text { work ability }\end{array} \\
\mathbf{n}(\%)\end{array}$} & \multirow[t]{2}{*}{$\mathbf{P}$} \\
\hline & & & & \\
\hline \multirow[t]{2}{*}{ Sex } & Female & $22(3.1)$ & $14(2.6)$ & 0.59 \\
\hline & Male & $678(96.9)$ & $520(97.4)$ & \\
\hline \multirow[t]{2}{*}{ Age } & $\leq 38$ years & $380(54.5)$ & $264(49.6)$ & 0.08 \\
\hline & $\geq 39$ years & $317(45.5)$ & $268(504)$ & \\
\hline \multirow[t]{3}{*}{ Educational level } & complete or incomplete graduate program & $84(12.0)$ & $53(9.9)$ & 0.48 \\
\hline & complete or incomplete undergraduate program & $492(70.3)$ & $388(72.7)$ & \\
\hline & Complete high school & $124(17.7)$ & $93(17.4)$ & \\
\hline \multirow[t]{2}{*}{ Weekly physical activity time } & 150 minutes or more & $382(54.6)$ & $245(46.0)$ & $<0.01$ \\
\hline & Less than 150 minutes & $317(45.4)$ & $288(54.0)$ & \\
\hline \multirow[t]{3}{*}{ Perception of chronotype } & Indifferent & $92(13.2)$ & $49(9.2)$ & 0.08 \\
\hline & Morningness or extreme morningness & $276(39.4)$ & $215(40.2)$ & \\
\hline & Eveningness or extreme eveningness & $332(47.4)$ & $270(50.6)$ & \\
\hline \multirow[t]{2}{*}{ Perception of sufficient sleep time } & Yes & $541(77.3)$ & $309(57.9)$ & $<0.01$ \\
\hline & No & $159(22.7)$ & $225(42.1)$ & \\
\hline \multirow[t]{3}{*}{ How well do you think you sleep } & Very well or well & $434(62.0)$ & $206(38.6)$ & $<0.01$ \\
\hline & Neither well, nor poorly & $228(32.6)$ & $235(44.0)$ & \\
\hline & Fairly or very poorly & $38(5.4)$ & $93(17.4)$ & \\
\hline \multirow[t]{2}{*}{ Obstructive sleep apnea syndrome } & Low chance & $601(85.9)$ & $382(71.5)$ & $<0.01$ \\
\hline & High chance & $99(14.1)$ & $152(28.5)$ & \\
\hline Sleepiness (Epworth) & Low sleepiness & $453(64.7)$ & $264(49.4)$ & $<0.01$ \\
\hline & Excessive sleepiness & $247(35.3)$ & $270(50.6)$ & \\
\hline Perception of fatigue & Lower fatigue & $557(84.6)$ & $304(60.7)$ & $<0.01$ \\
\hline & Higher fatigue & $101(15.4)$ & $197(39.3)$ & \\
\hline Unintentional nap during work & No & $364(52.0)$ & $157(29.4)$ & $<0.01$ \\
\hline & Yes & $336(48.0)$ & $377(70.6)$ & \\
\hline Symptoms of insomnia & Without symptoms & 391 (56.9) & $170(32.5)$ & $<0.01$ \\
\hline & With symptoms & $296(43.1)$ & $353(67.5)$ & \\
\hline Current function & International captain & $29(4.1)$ & $48(9.0)$ & $<0.01$ \\
\hline & Domestic captain & $347(49.6)$ & $291(54.5)$ & \\
\hline & International copilot & $17(2.4)$ & $19(3.6)$ & \\
\hline & Domestic copilot & $307(43.8)$ & $176(32.9)$ & \\
\hline Flight routes & Domestic & $654(93.4)$ & $467(87.5)$ & $<0.01$ \\
\hline & International & $46(6.6)$ & $67(12.5)$ & \\
\hline Monthly flight hours & Up to 65 hours & $356(51.5)$ & $217(41.1)$ & $<0.01$ \\
\hline & 66 hours or more & $335(48.5)$ & $311(58.9)$ & \\
\hline Average days off per month & 10 days or more & $338(48.3)$ & $176(33.0)$ & $<0.01$ \\
\hline & Up to 9 days & $362(51.7)$ & $357(67.0)$ & \\
\hline Maximum number of consecutive days of work & Up to 6 days & $591(84.8)$ & $408(77.3)$ & $<0.01$ \\
\hline & 7 days or more & $106(15.2)$ & $120(22.7)$ & \\
\hline Maximum number of consecutive nights of work & One or two nights & $122(18.1)$ & $82(15.9)$ & 0.19 \\
\hline & Three or four nights & $386(57.4)$ & $283(55.1)$ & \\
\hline & Five nights or more & $165(24.5)$ & $149(29.0)$ & \\
\hline Frequency of of operational flight delays & Never, rarely or sometimes & $472(67.4)$ & $261(48.9)$ & $<0.01$ \\
\hline & Often or always & $228(32.6)$ & $273(51.1)$ & \\
\hline Time working as a pilot & Up to 10 years & $324(46.3)$ & $181(34.1)$ & $<0.01$ \\
\hline & 11 to 20 years & $192(27.4)$ & $206(38.8)$ & \\
\hline & 21 to 30 years & $114(16.3)$ & $115(21.8)$ & \\
\hline & 31 years or more & $70(10)$ & $31(5.3)$ & \\
\hline Time working in the night shift & Less than 1 year & $404(57.7)$ & $272(50.9)$ & $<0.01$ \\
\hline & 1 to 5 years & $130(18.6)$ & $90(16.9)$ & \\
\hline & 6 to 10 years & $81(11.6)$ & $83(15.5)$ & \\
\hline & 11 to 15 years & $27(3.8)$ & $41(7.7)$ & \\
\hline & 16 years or more & $58(8.3)$ & $48(9.0)$ & \\
\hline Quality of place for resting in the plane & $\geq 11$ points & $353(51.1)$ & $228(43.3)$ & $<0.01$ \\
\hline & $\leq 10$ points & $337(48.8)$ & $299(56.7)$ & \\
\hline End of work in the night shift & Before 5:00 am & $358(55.0)$ & $239(47.2)$ & $0.02 *$ \\
\hline & Between 5:01 am and 8:00 am & $229(35.2)$ & $194(38.3)$ & \\
\hline & Between 8:01 am and 12:00 pm & $60(9.2)$ & $67(13.3)$ & \\
\hline & Between 12:01 pm and 4:00 pm & $4(0.6)$ & $6(1.2)$ & \\
\hline Need for recovery after work & Less need & $315(45.0)$ & $77(14.4)$ & $<0.01$ \\
\hline & Moderate need & $228(32.6)$ & $200(37.5)$ & \\
\hline & Greater need & $157(22.4)$ & $257(48.1)$ & \\
\hline Occupational stress & Low job strain & $79(11.3)$ & $113(21.2)$ & $<0.01$ \\
\hline & Passive work & $180(25.7)$ & 99 (18.5) & \\
\hline & High job strain & $287(41.0)$ & $147(27.5)$ & \\
\hline & Active work & $154(22.0)$ & $175(32.8)$ & \\
\hline
\end{tabular}

\footnotetext{
* Fisher's exact test
} 
Table 2. Gross and adjusted prevalence ratios of factors associated with moderate or low work ability of regular aviation pilots. Brazil, 2017.

\begin{tabular}{|c|c|c|}
\hline \multirow{2}{*}{ Variable } & \multirow{2}{*}{$\begin{array}{c}\text { Bivariate } \\
\text { PR }(95 \% \mathrm{CI})\end{array}$} & \multirow{2}{*}{$\begin{array}{c}\text { Adjusted multiple* } \\
\text { PR }(95 \% \mathrm{CI}) \\
\end{array}$} \\
\hline & & \\
\hline \multicolumn{3}{|l|}{ Weekly physical activity time } \\
\hline More than 150 minutes & 1 & \\
\hline Up to 150 minutes & $1.22(1.03-1.44)$ & \\
\hline \multicolumn{3}{|l|}{ Perception of chronotype } \\
\hline Indifferent & 1 & \\
\hline Morningness or extreme morningness & $1.26(0.92-1.72)$ & \\
\hline Eveningness or extreme eveningness & $1.29(0.95-1.75)$ & \\
\hline \multicolumn{3}{|l|}{ Perception of sufficient sleep time } \\
\hline Yes & 1 & 1 \\
\hline No & $1.61(1.36-1.92)$ & $1.29(1.06-1.57)$ \\
\hline \multicolumn{3}{|l|}{ How well do you think you sleep } \\
\hline Very well or well & 1 & \\
\hline Neither well nor poorly & $1.57(1.31-1.90)$ & \\
\hline Fairly or very poorly & $2.20(1.73-2.82)$ & \\
\hline \multicolumn{3}{|l|}{ Obstructive sleep apnea syndrome } \\
\hline Low chance & 1 & \\
\hline High chance & $1.55(1.29-1.88)$ & \\
\hline \multicolumn{3}{|l|}{ Sleepiness (Epworth) } \\
\hline Low sleepiness & 1 & \\
\hline Excessive sleepiness & $1.41(1.19-1.68)$ & \\
\hline \multicolumn{3}{|l|}{ Perception of fatigue } \\
\hline Lower fatigue & 1 & 1 \\
\hline Higher fatigue & $1.87(1.56-2.23)$ & $1.51(1.24-1.84)$ \\
\hline \multicolumn{3}{|l|}{ Unintentional nap during work } \\
\hline No & 1 & \\
\hline Yes & $1.75(1.46-2.11)$ & \\
\hline \multicolumn{3}{|l|}{ Symptoms of insomnia } \\
\hline Without symptoms & 1 & \\
\hline With symptoms & $1.79(1.49-2.15)$ & \\
\hline \multicolumn{3}{|l|}{ Current function } \\
\hline International captain & 1 & \\
\hline Domestic captain & $0.73(0.54-0.99)$ & \\
\hline International copilot & $0.85(0.49-1.44)$ & \\
\hline Domestic copilot & $0.58(0.43-0.81)$ & \\
\hline \multicolumn{3}{|l|}{ Flight routes } \\
\hline Domestic & 1 & \\
\hline International & $1.42(1.11-1.84)$ & \\
\hline \multicolumn{3}{|l|}{ Monthly flight hours } \\
\hline Up to 65 hours & 1 & 1 \\
\hline 66 hours or more & $1.27(1.07-1.51)$ & $1.22(1.01-1.46)$ \\
\hline \multicolumn{3}{|l|}{ Average days off per month } \\
\hline 10 days or more & 1 & 1 \\
\hline Up to 9 days & $1.45(1.21-1.74)$ & $1.27(1.04-1.55)$ \\
\hline \multicolumn{3}{|c|}{ Maximum number of consecutive days of work } \\
\hline Up to 6 days & 1 & \\
\hline 7 days or more & $1.30(1.06-1.59)$ & \\
\hline \multicolumn{3}{|c|}{ Maximum number of consecutive nights of work } \\
\hline One or two nights & 1 & \\
\hline Three or four nights & $1.05(0.83-1.35)$ & \\
\hline Five nights or more & $1.18(0.91-1.55)$ & \\
\hline \multicolumn{3}{|l|}{ Frequency of operational flight delays } \\
\hline Never, rarely or sometimes & 1 & 1 \\
\hline Often or always & $1.53(1.29-1.81)$ & $1.23(1.02-1.48)$ \\
\hline
\end{tabular}


Table 2. Gross and adjusted prevalence ratios of factors associated with moderate or low work ability of regular aviation pilots. Brazil, 2017. Continuation

\begin{tabular}{|c|c|}
\hline \multicolumn{2}{|l|}{ Time working as a pilot } \\
\hline Up to 10 years & 1 \\
\hline 11 to 20 years & $1.44(1.18-1.76)$ \\
\hline 21 to 30 years & $1.40(1.10-1.77)$ \\
\hline 31 years or more & $0.85(0.58-1.25)$ \\
\hline \multicolumn{2}{|l|}{ Years working night shifts } \\
\hline Less than 1 year & 1 \\
\hline 1 to 5 years & $1.02(0.81-1.29)$ \\
\hline 6 to 10 years & $1.26(0.98-1.60)$ \\
\hline 11 to 15 years & $1.49(1.08-2.08)$ \\
\hline 16 years or more & $1.13(0.83-1.53)$ \\
\hline \multicolumn{2}{|l|}{ Quality of place for resting in the plane } \\
\hline$\geq 11$ points & 1 \\
\hline$\leq 10$ points & $1.19(1.00-1.43)$ \\
\hline \multicolumn{2}{|l|}{ End of work in the night shift } \\
\hline Before 5:00 am & 1 \\
\hline Between 5:01 am and 8:00 am & $1.15(0.95-1.38)$ \\
\hline Between 8:01 am and 12:00 pm & $1.32(1.00-1.73)$ \\
\hline Between 12:01 pm and 4:00 pm & $1.49(0.66-3.37)$ \\
\hline \multicolumn{2}{|l|}{ Need for recovery after work } \\
\hline Less need & 1 \\
\hline Moderate need & $2.38(1.83-3.09)$ \\
\hline Greater need & $3.16(2.45-4.07)$ \\
\hline \multicolumn{2}{|l|}{ Occupational stress } \\
\hline Low job strain & 1 \\
\hline Passive work & $0.61(0.46-0.79)$ \\
\hline High job strain & $0.57(0.45-0.74)$ \\
\hline Active work & $0.91(0.72-1.14)$ \\
\hline
\end{tabular}

While in the multiple model adjusted for sex and age, the variables that presented risk of prevalence for low or moderate work ability were: insufficient sleep, higher perception of fatigue, 66 or more monthly flight hours, less than 10 days off per month, and frequent operational delays (Table 2).

\section{DISCUSSION}

We observed a relevant percentage of pilots with moderate or low work ability, which is an important aspect, because the study population consisted of young adults and the main factors associated with decreased work ability are related to work organization. Sluiter ${ }^{24}$ points out that functions with high demand of work, as in the case of airline pilots, impair work ability, even in younger workers ${ }^{4,24}$. In this study, we observed higher proportion of pilots with an active work, that is, with high demand and high control, with moderate or low work ability, in relation to great or good work ability.

When comparing the prevalence of moderate or low work ability of this study with others that used the same evaluation tool, we found that it was very high. Marqueze and Moreno ${ }^{12}$, studying higher education professors with similar mean age to that of the pilots, found a prevalence of $13 \%$. It is worth mentioning that the professors worked on the day, evening, 
and night shifts until $11 \mathrm{pm}$. Two studies with nursing professionals observed prevalence of moderate or low work ability lower than or equal to that of the pilots in this article. The nursing professionals' mean age was 39.4 years and 41.3 years and they also worked in shifts and at night. The prevalence of moderate or low work ability was $35 \%^{5}$ and $43.3 \%^{21}$. It should be pointed out that the study of Prochnow et al. ${ }^{21}$ used the cut-off point established by Tuomi et al. ${ }^{25}$, which is proposed for workers aged from 45 years. While the study of Silva et al. ${ }^{5}$ used the cut-off point of Tuomi et al..$^{25}$ and that of Kujala et al. ${ }^{10}$, according to the age of respondents. However, in this study, we employed only the cut-off point proposed by Kujala et al. ${ }^{10}$, because it is indicated for younger workers, as in the case of the sample under study ( $74.2 \%$ of the pilots were aged up to 45 years). In the study of Kujala et al. ${ }^{10}$, with Finnish workers of different occupational areas, the prevalence of moderate and low work ability was also lower than in our study $(39.0 \% \text { in men })^{10}$.

The respondents' age is an aspect that needs to be highlighted, because, on average, the pilots studied were young adults, but already showed signs of impaired work ability. According to Tuomi et al..$^{25}$, functional aging is expected as chronological age advances; however, in this study age was not associated with low or moderate work ability. In the study of Marqueze and Moreno ${ }^{12}$, the authors also did not observe this relationship and said that functional aging is not necessarily related to chronological aging, but mainly to working conditions, which seems to be the same situation for the pilots in the study. As described previously, airline pilot work is complex and requires different skills and activities from the professional, mainly mental requirements. These work requirements can trigger chronic and acute physiological responses, psychological reactions, and behavioral changes, with the possibility of decreased work ability .

It was found that insufficient sleep was a factor associated with moderate or low work ability. According to Melo and $\mathrm{Neto}^{14}$, sleep deprivation in pilots is a reflection of irregular workdays. It is known that sleep restriction for a prolonged time can cause fatigue, leading to decreased level of alert and increased irritability, among other negative effects ${ }^{13,15,20,22}$. Fatigue was also one of the factors associated with moderate or low work ability. This result corroborates the study of Silva et al. ${ }^{5}$, in which the authors found that the higher the fatigue, the lower the work ability.

Sleep deprivation increases the possibility of unintentional naps during the flight ${ }^{13}$, and one of the factors that lead to this greater sleep deprivation is the reversal of the sleepwake cycle because of exposure to work in irregular shifts ${ }^{7,11,20,23}$. As verified, perception of insufficient sleep increased by almost $30 \%$ the prevalence of moderate or low work ability. Most pilots reported starting the morning shift before 5:00 am and ending the evening shift after 10:00 pm, in addition to often working the night shift, thus affecting negatively the time available for sleep. According to Goode ${ }^{6}$, pilots should have the opportunity to sleep at least eight hours in the rest time. This could improve work ability, as well as avoid incidents.

In this study, increased flight hours ( $\geq 66$ hours/month) was a factor associated with moderate or low work ability. Roach et al..$^{22}$ and Lamond et al. ${ }^{11}$ claim that short workweeks (less than 40 hours/week), although less extensive, have shorter rest time between workdays, which leads to fatigue. While average workweeks (40-61 hours/week) and long workweeks (over 62 hours/week) have longer rest time between work periods. However, more extensive work periods are harmful to health, as verified in this study. Thus, the authors recommend increased rest time between work periods, as well as shorter work periods, given the complexity and volume of the pilots' work ${ }^{11,22}$. It is pointed out that the flight hours reported by study participants did not exceed those provided for in law (80 hours/month - Law 13.475 of August 28, 2017 $)$. However, a study limitation is that we collected no information on total workday (timetables for report, for engine shutdown, and duration of operational delays); therefore, actual flight hours are less than total work time.

${ }^{c}$ Brasil. Lei $\mathrm{n}^{\circ} 13.475$, de 28 de agosto de 2017. Dispõe sobre o exercício da profissão de tripulante de aeronave, denominado aeronauta; e revoga a Lei $\mathrm{n}^{\circ} 7.183$, de 5 de abril de 1984. Brasília (DF); 2017 [cited 2017 Dec 13]. Available from: http://www.planalto.gov.br/ ccivil_03/_ato2015-2018/2017/ lei/L13475.htm

Having less than 10 days off per month was also a factor associated with low or moderate work ability. Working for a long consecutive time, without time off, and with an extensive 
work period, considering the high cognitive demands of the profession, can lead to a situation of fatigue and, consequently, decreased work ability ${ }^{5,7,9}$.

Frequent operational delays have also been associated with low or moderate work ability. According to Law $13,475^{\circ}$, a workday is counted from the time of report to the workplace, which should be at least 30 minutes before the flight, and ends 30 minutes after the final stop of engines for domestic flights and 45 minutes for international flights. Therefore, it is understood that a delay or even small delays could increase the workday of the pilot, who is already working on the limit ${ }^{6,7}$, which leads to increased fatigue.

In the bivariate model, in addition to the factors already reported in the multiple model, other aspects related to sleep were also associated with low or moderate work ability. These factors include: poor perception of sleep, excessive sleepiness, unintentional naps during work, and symptoms of insomnia. This result reinforces how sleep problems may influence work ability ${ }^{5}$. According to Itani ${ }^{9}$, harmful effects were observed in the health of pilots working in irregular shifts and with poor conditions of rest, such as inadequate place for rest on the plane and little time to sleep.

Aspects concerning work organization were also associated with low or moderate work ability in the bivariate model. Among them: international flight routes, consecutive work for five nights or more, longer career and more time on the night shift, a place with poor quality for rest on the plane, end of night shift between $12 \mathrm{pm}$ and $4 \mathrm{pm}$, and need for longer recovery. These factors indicate that organizational aspects that directly affect the rest of pilots can lead to early functional aging, which requires actions to minimize this impact, as pointed out previously.

While aspects related to occupational stress were factor of protection; however, prolonged exposure of workers to work stressors may be related to the emergence of musculoskeletal symptoms and early functional aging ${ }^{25}$. Menegon ${ }^{\mathrm{d}}$ also found that working time and workplace had important role in decreasing the work ability of individuals working in structural assembly of aircraft. The data presented above corroborate the hypothesis that work organization has major influence on work ability, and that working hours may be central in this discussion.

This study presents some limitations, which do not allow generalizations of results found. We used convenience sampling, since only pilots associated with the ABRAPAC were invited to participate in the study. However, internal validity was high ( $99 \%$ sample power), and around $25 \%$ of the total Brazilian pilots registered in the Anac ${ }^{\text {a }}$ composed the sample. Another limiting factor refers to the insomnia symptoms questionnaire. This questionnaire had no validation and translation to Portuguese, which may be considered a bias in the study. However, it should be noted that this questionnaire has been used in some Brazilian studies $^{16}$, and in this study showed a high degree of reliability and consequent validation verified by Cronbach's alpha.

Additionally, the study design (cross-sectional) does not allow to determine the temporal relationship of the variables studied. However, such studies are fundamental to know the sociodemographic, work, and sleep characteristics of this population and may be a reference for future studies. With the significant increase in demand for air travel, the decreasing number of pilots, and the consequent overworking, the risk of deleterious effects to the health of this professional category is considerable and would generate great impact on the economy. Therefore, disease prevention and health promotion actions are essential to avoid this situation. It is pointed out that there are no records of previous Brazilian studies similar to this, as to sample size and diversity of pilots, since they worked in the five major commercial airlines in the country.

Finally, we can conclude that work organization was a determining factor for decreased work ability, especially concerning aspects related to rest and its repercussions on the sleep of pilots. 


\section{REFERENCES}

1. Akerstedt T, Fredlund P, Gillberg M, Jansson B. Work load and work hours in relation to disturbed sleep and fatigue in a large representative sample. J Psychosom Res. 2002;53(3):741-8. https://doi.org/10.1016/S0022-3999(02)00447-6

2. Alves MGM, Chor D, Faerstein E, Lopes CS, Wernek GL. Versão resumida da "job stress scale": adaptação para o português. Rev Saude Publica. 2004;38(2):164-71. https://doi.org/10.1590/S0034-89102004000200003

3. Bertolazi AN, Fagondes SC, Hoff LS, Pedro VD, Menna Barreto SS, Johns MW. Validação da escala de sonolência de Epworth em português para uso no Brasil. J Bras Pneumol. 2009:35(9):877-83. https://doi.org/10.1590/S1806-37132009000900009

4. Bethge M, Radoschewski, FM. Physical and psychosocial work stressors, health-related control beliefs and work ability: cross-sectional findings from German Sociomedical Panel of Employess. Int Arch Occup Environ Health. 2010;83(3):241-50. https://doi.org/10.1007/s00420-009-0442-5

5. Silva FJ, Felli VE, Martinez MC, Mininel VA, Ratier AP. Association between work ability and fatigue in Brazilian nursing workers. Work. 2015;53(1):225-32. https://doi.org/10.3233/WOR-152241

6. Goode JH. Are pilots at risk of accidents due fatigue? J Safety Res. 2003;34(3):309-13. https://doi.org/10.1016/S0022-4375(03)00033-1

7. Gregory KB, Winn W, Johnson K, Rosekind MR. Pilot fatigue survey: exploring fatigue factors in air medical operations. Air Med J. 2010;29(6):309-19. https://doi.org/10.1016/j.amj.2010.07.002

8. Ilmarinen J. Aging workers. Occup Environ Med. 2001;58(8):546-52. https://doi.org/10.1136/oem.58.8.546

9. Itani A. Saúde e gestão na aviação: a experiência de pilotos e controladores de tráfego aéreo. Psicol Soc. 2009;21(2):203-12. https://doi.org/10.1590/S0102-71822009000200007

10. Kujala V, Remes J, Ek E, Tammelin T, Laitinen J. Classification of Work Ability Index among young employees. Occup Med (Lond). 2005;55(5):399-401. https://doi.org/10.1093/occmed/kqi075

11. Lamond N, Petrilli RM, Dawson D, Roach GD. Do short international layovers allow sufficient opportunity for pilots to recover? Chronobiol Int. 2006;23(6):1285-94. https://doi.org/10.1080/07420520601062387

12. Marqueze EC, Moreno CRC. Satisfação no trabalho e capacidade para o trabalho entre docentes universitários. Psicol Estud. 2009;14(1):75-82. https://doi.org/10.1590/S1413-73722009000100010

13. Marqueze EC, Nicola ACB, Diniz DHMD, Fischer FM. Jornadas de trabalho associadas a cochilos não intencionais entre pilotos da aviação regular. Rev Saude Publica. 2017;51:61. https://doi.org/10.1590/S1518-8787.2017051006329

14. Melo MFS, Silvany Neto AM. Perfil de morbidade, aspectos ergonômicos e psicossociais, fadiga e perturbação do ciclo circadiano de pilotos de aviação comercial: uma revisão narrativa. Rev Baiana Saude Publica. 2012;36(3):683-98. https://doi.org/10.22278/2318-2660.2012.v36.n3.a547

15. Moreno CRC. Sono e estratégias relativas ao sono para lidar com horários de trabalho. In: Fischer FM, Moreno CRC, Rotenberg L. Trabalho em turnos e noturno na sociedade 24 horas. São Paulo: Atheneu; 2003. p.43-52.

16. Moreno CRC, Lowden A, Vasconcelos S, Marqueze EC. Musculoskeletal pain and insomnia among workers with different occupations and working hours. Cronobiol Int. 2016:33(6):749-53. https:// doi.org/10.3109/07420528.2016.1167730

17. Netzer NC, Stoohs RA, Netzer CM, Clark K, Strohl KP. Using the Berlin Questionnaire to identify patients at risk for the sleep apnea syndrome. Ann Intern Med. 1999;131(7):485-91. https://doi.org/10.7326/0003-4819-131-7-199910050-00041

18. Nordin M, Åkerstedt T, Nordin S. Psychometric evaluation and normative data for the Karolinska Sleep Questionnaire. Sleep Biol Rhythms. 2013;11(4):216-26. https://doi.org/10.1111/sbr.12024

19. Pate RR, Pratt M, Blair SN, Haskell WL, Macera CA, Bouchard C, et al. Physical activity and public health. A recommendation from the Centers for Disease Control and Prevention and the American College of Sports Medicine. JAMA. 1995;273(5):402-7. https://doi.org/10.1001/jama.1995.03520290054029

20. Petrilli RM, Roach GD, Dawson D, Lamond N. The sleep, subjective fatigue, and sustained attention of commercial airline pilots during an international pattern. Chronobiol Int. 2006;23(6):1357-62. https://doi.org/10.1080/07420520601085925 
21. Prochnow A, Magnago TSBS, Urbanetto JS, Beck CLC, Lima SBS, Greco PBT. Work ability in nursing: relationship with psychological demands and control over the work. Rev Lat Am Enfermagem. 2013;21(6):1298-305. https://doi.org/10.1590/0104-1169.3072.2367

22. Roach GD, Petrilli RM, Dawson D, Lamond N. Impact of layover length on sleep, subjective fatigue levels, and sustained attention of long-haul airline pilots. Chronobiol Int. 2012;29(5):580-6. https://doi.org/10.3109/07420528.2012.675222

23. Runeson R, Lindgren T, Wahlstedt K. Sleep problems and psychosocial work environment among Swedish commercial pilots. Am J Ind Med. 2011;54(7):545-51. https://doi.org/10.1002/ajim.20943

24. Sluiter JK. High-demand jobs: age-related diversity in work ability? Appl Ergon. 2006;37(4):429-40. https://doi.org/10.1016/j.apergo.2006.04.007

25. Tuomi K, Ilmarinen J, Jahakola A, Katajarinne L, Tulkki A. Índice de capacidade para o trabalho. Instituto Finlandês de Saúde Ocupacional. São Carlos (SP): EDUFSCAR, 2005.

26. Veldhoven M, Broersen S. Measurement quality and validity of the "need for recovery scale". Occup Environ Med. 2003;60 Suppl 1:i3-9. https://doi.org/10.1136/oem.60.suppl_1.i3

27. Yoshitake $\mathrm{H}$. Relations between the symptoms and the feelings of fatigue. Ergonomics. 1971;14(1):175-86. https://doi.org/10.1080/00140137108931236

Funding: Coordenação de Aperfeiçoamento de Pessoal de Nível Superior (CAPES - master’s scholarship Process 1439999/2014).

Authors' Contribution: Data collection: ECM. Study conception and design, data analysis and interpretation: PP, ECM. Writing of the manuscript: PP, ECM. Relevant critical review of the intellectual content of the manuscript: PP, ECM. Final approval of the manuscript and responsibility for all aspects of the work: PP, ECM.

Acknowledgements: Brazilian Association of Civil Aviation Pilots (ABRAPAC) for permission to conduct this study with its associates.

Conflict of interest: The authors declare no conflict of interest. 